\title{
Local Business Exploration in Barabai City as a Resource of Economic Learning in SMA
}

\author{
Zainur Nor $^{1 *}$ Rizali Hadi ${ }^{1}$ Monry Fraick Nicky Gillian Ratumbuysang ${ }^{1}$ \\ ${ }^{1}$ Economic Education Department, Faculty of Teacher Training and Education, Lambung Mangkurat University, \\ Banjarmasin, Indonesia \\ ${ }^{*}$ Corresponding author.E-mail:oliveor.zn@gmail.com
}

\begin{abstract}
This research was carried out in the Hulu Sungai Tengah Regency precisely in the City of Barabai. The purpose of this study is to identify a picture of the contribution of local businesses to the activities of the sale of apam barabai storms and the use of these local businesses to serve as a source of economic learning. This research uses a qualitative approach. With as many as four informants. Data analysis techniques using data reduction analysis, data display, and conclusion drawing / verification with the triangulation credibility test. The results showed that local businesses in the sale of fire pawns are the main occupations and are very helpful in family income, and the local businesses are also in economic activities.
\end{abstract}

Keywords: Local business, learning resources, economic learning.

\section{INTRODUCTION}

Nowadays, teachers are no longer the only people as a source of learning, because along with the development of the times in the form of developments in technology science. The teacher's insight may be the same as the student's, perhaps even the student may know earlier than the teacher. All of this happened because of the rapid development of technology and information, which is happening in our environment today, so that teachers are no longer the only source of learning. Which here the teacher only has a broader element where the teacher is only a provider of learning facilities, so that students are willing to learn. As a motivator who gives enthusiasm to students and energy to continue learning.

In relation to learning, learning is one of the factors that can influence the character of students and also plays an important role in the formation of a human personality, which is continuous regardless of social or economic conditions. Learning is also said to be an agenda that can be carried out in a manner where what should be meant is that which is related to a person's mental processes, for example activities in thinking, listening, understanding, concluding and so on. As well as a process with implementation, for example practice, experimentation and so on.

These potentials, which are scattered in the surrounding community or in the school environment in the form of learning resources, should be an important concern for teachers to be organized wisely so that they can be of positive use, to achieve student learning success. Therefore, teachers must try to use various existing learning resources in an innovative manner and provide many opportunities for students to interact with various learning resources around them.

In this case, it requires good learners, learners, and learning resources, in the form of knowledge, attitudes, skills, art, religion, and social values. To fulfill these three elements (learners, learners, and learning resources) and to realize the level of success, several components are needed, including learning materials, methods, strategies, models, approaches to learning, learning media, learning objectives and evaluation in learning [1].

Learning resources are everything that is around our environment as a unit of learning which can be functionally used to help optimize the process and learning outcomes. Thus, learning resources are one component of learning activities, which enable a person to gain knowledge, abilities, attitudes, beliefs, emotions, and feelings [2]. Learning resources also provide a learning experience, and without learning it is impossible to carry out a learning process properly. In its application, the use of a learning resource in the learning process which has been stated in the current curriculum, that effective learning is a learning process that uses a variety of learning resources.

Learning resources are something in the environment that can be functionally used to help the learning process and outcomes. In economic learning resources, students can identify and optimize these learning resources in economic learning to help and understand that the economy is a part of human life, not just a subject.

Learning resources are not only tools and materials that are used in learning, but also include people, budgets and facilities or facilities. What is included in the learning resource is its availability to help someone in learning. According to [3] Learning resources are divided into six types, namely messages, people, materials, tools, techniques, and backgrounds or environments where they are used as learning resources in learning activities and can improve the quality of learning [4].

Therefore, there are so many learning resources around our environment, all of which can be used as a necessity for 
learning. The various kinds of learning resources that are so diverse in our environment and the students themselves, whether designed or not designed, have generally not maximized their utilization. With the existence of learning resources based on local wisdom (local business) which hopefully can increase learning knowledge in life. Local businesses are also classified as industrial businesses, which are a group of industries that depend for their survival on businesses that are run on a limited local market, and are relatively scattered in terms of location [5].
Industry is a livelihood sector which uses or utilizes agricultural products where the processing comes from raw materials, then processed into semi-finished goods, and processed into finished goods that are ready to be used or consumed in daily life. In producing industrial production, not only in the form of goods, but also in the form of services [6], [7].

Based on the results of preliminary research, regarding the number of businesses or companies and workers based on the classification of industries located in Hulu Sungai Tengah district in 2017, at table 1 are as follows:

Table 1 Number of Companies and Workers according to Industry Classification in Hulu Sungai Tengah Regency, 2017

\begin{tabular}{|l|c|c|}
\hline \multicolumn{1}{|c|}{ KLUI Sub-Sector Type of Industry } & Business unit & Labor \\
\hline Beverage, food and tobacco industries & 382 & 921 \\
\hline Apparel \& leather, and textile industry & 80 & 110 \\
\hline Wood, bamboo, grass rattan \& the like industry including household furniture & 243 & 609 \\
\hline Paper and paper goods industry, printing publisher & 1 & 4 \\
\hline Chemical industry and goods made from chemicals, petroleum & - & - \\
\hline Non-metal minerals industry & 25 & 89 \\
\hline Metal goods industry, machinery \& equipment & 121 & 244 \\
\hline Industrial services & - & - \\
\hline \multicolumn{1}{|c|}{ Amount } & $\mathbf{8 5 2}$ & $\mathbf{1 , 9 7 7}$ \\
\hline
\end{tabular}

The results of the introduction to industrial business obtained from the Central Bureau of Statistics of Hulu Sungai Tengah Regency which from the Industry, Mining and Energy Office recorded that during 2017 there were 852 companies both informal and formal. All of these companies are able to absorb a workforce of 1,977 people. The industries that absorb the most labor are the food, muniman and tobacco industries with 921 workers.

Table 2 Number of Trading Facilities by Type in Hulu Sungai Tengah Regency, 2013-2017

\begin{tabular}{|l|l|l|l|l|l|}
\hline \multicolumn{1}{c}{ Trade Facilities } & \multicolumn{1}{c|}{$\mathbf{2 0 1 3}$} & $\mathbf{2 0 1 4}$ & $\mathbf{2 0 1 5}$ & \multicolumn{1}{|c|}{$\mathbf{2 0 1 6}$} & \multicolumn{1}{|c|}{$\mathbf{2 0 1 7}$} \\
\hline Market & 16 & 16 & 16 & 13 & 13 \\
\hline Store & 1,750 & 1,750 & 1,750 & 1,750 & 1,750 \\
\hline Stall & 3,145 & 3,145 & 3,145 & 345 & 345 \\
\hline Shop & 19 & 19 & 19 & 25 & 25 \\
\hline Basics / stalls & 2,961 & 2,961 & 2,961 & 2,961 & 2,961 \\
\hline
\end{tabular}

According to the records of the Trade Office, in 2017 Hulu Sungai Tengah Regency had 2,545 traders, 2,477 of whom were small traders and the rest were middle traders. To accommodate these traders, trading facilities were built by both the government and the private sector, during 2017 there were 13 markets, 1,750 shops, 3,145 stalls / booths, 25 stalls and 2,961 basics or lapak.

Based on this, industrial and trading businesses are the lifeblood of the surrounding community. This is evident from some of the people who depend on doing business. Of course this is related to the role of economic actors in economic activities in some communities in Kab. Hulu Sungai Tengah which is interesting to review. Because the role of economic actors in economic activities is a reflection of behavior in an economic activity in terms of trading business.

This topic is interesting to research, considering that today most of them only rely on the internet site (google) which is used as a reference as a learning resource other than those provided by schools [8]-[10]. Also some of their teachers have never used local learning resources in learning, because the learning resources used have been provided by the school, require a long time, have broad insight, and are also limited in learning resources based on local wisdom. Based on the foregoing, which today in learning always develops in accordance with the demands of the times, both in its implementation, in models, and in the media of learning resources [11]. Where schools teach from a variety of theories in economic learning, no one has made a learning resource for local business-based economic discussions. Therefore, researchers are interested in raising local businesses in the city of Barabai to serve as a source of economic learning.

In essence, learning is a process in which there are interactions or activities in students whose all conditions exist in the environment around these students. Learning, can also be seen as the existence of a process that leads to the achievement of goals and processes in action by means of various creativities and innovations made by the teacher [12],[13].

In a lesson, on external factors, for example in Student Worksheets (LKPD), media and other learning resources, 
both those that are planned which are in accordance with the student's internal situation. Designing learning activities, there is an effort so that the learning process achieves a goal in certain learning. So, it can be understood that learning is a learning agenda that can enable these students to gain a sufficient learning experience.

Economic learning is a social science that studies human behavior in an effort to meet their needs with infinite fulfillments while the means of satisfying their needs are limited. Economics is the science of where there is action in choosing from a variety of available alternatives. Economics is a science that studies from various combinations of production factors, both those that can produce production in the form of goods or in the form of services, which are in order to meet human needs in life.

In general, economics is defined as a social science that studies human behavior in utilizing limited resources to meet their daily needs, both in the form of goods and services.

In this description, we can conclude that economic learning is a part of social science that is concerned with people's behavior for their daily needs as well as in decision making. According to the Regulation of the Minister of Education and Culture No.24 of 2016 for the 2013 curriculum, the Core Competency (KI) contains the level of ability to achieve the Pass Competency Standards (SKL) that a student must have at each grade level. Meanwhile, in Basic Competencies (KD), it includes the ability and skills in learning materials that are at least achieved by students in a certain subject in each educational unit that spurs on the KI. And seen from the 2013 curriculum at the Education Unit Level, economic subjects at the Senior High School (SMA) level as a subject in the Social Sciences (IPS) major are undertaken by eleventh grade students. Whereas in the K13, At the primary level schools, economics is only an integration of Social Sciences (IPS), while at secondary education, economics is given as a separate subject. Economic learning for the Senior High School / Madrasah Aliyah level aims to enable these students to have an ability, understanding and sensitivity to current economic growth, which is stated in Government Regulation No.22 of 2006 related to Content Standards / Competency Standards Basic, namely in the formation of a wise, rational and responsible attitude by having useful knowledge and skills in economics, be it for oneself, household, society and the country.

\section{RESEARCH METHOD}

This type of research is descriptive qualitative, which aims to describe the role of economic actors in economic activities in local businesses in terms of selling wadai apam barabai as a source of economic learning. The approach taken is a qualitative approach, which is explained based on the results of data collection in the field by conducting interviews, observation and documentation [14]-[16].

In qualitative research, it is not familiar with the sample or population, but by using the object of research which is only the informant who knows deeply about the problem being researched. By taking as many as four informants, by gender and age/age category.

The data source used is the primary data source, which is obtained from the results of interviews, observations and documentation of several related parties. The instruments in this study included interview guidelines, observation guidelines and documentation study guidelines.

In data collection techniques, which is applied in this research is to make observations, interviews and documentation. By checking the validity of the data studied, namely using triangulation techniques, to test the credibility of data from interviews, observation and documentation.

The data analysis technique in this study was carried out when data collection took place and after completing data collection in a certain period which used Miles and Huberman's models, namely data reduction, data display and conclusion drawing / verification, to determine the contribution of local businesses to economic activities and their relationship. with high school economics learning resources.

\section{RESULTS AND DISCUSSION 3.1 Research Findings}

Based on the results of the research, it can be seen that local businesses in selling wadai apam barabai can be seen from several aspects, namely: social, economic, employment, activity, product assurance, and business preservation. By gender category and age difference.

On the social aspect, it shows that the average wadai apam trader at the level of knowledge knows that there are various kinds of wadai that are sold not only wadai apam barabai but such as wadai rings, lam cakes, peanuts, and many more. And on average, all wadai apam traders already know that the characteristic of the Kota Barabai cake is wadai apam barabai.

On the economic aspect, it shows that local businesses in the city of Barabai are used for production, distribution and consumption activities. In the perspective of product sales activities, the results of the study indicate that there is a common view in the allocation of income from the business to be used for primary (basic) needs, which are to meet family needs. Local business in selling wadai apam has an important role in one's survival, because it is a source of income in life [17]-[19].

In the aspect of job selection or business selection, the business of selling wadai apam is the main job, and if the wadai apam is still left over or has not been sold out, then the method for the seller is to bring the wadai apam back home to be steamed again so that it can be sold. last for hours.

It is the same with other aspects, namely activities in the manufacture or processing of wadai apam, the urge to learn about fiber related to its marketing, the way the seller trades his business.

In the aspect of product guarantee, the seller assures that the wadai apam can last for two days. And in the aspect of business preservation here, it is related to inheritance in which the business will be continued to their children or 
relatives in order to survive in defending the local business, namely the business of selling wadai apam barabai [20]. Where all these aspects relate to the role of economic behavior in economic activities including: the level of knowledge of the seller on the type of business being traded, the existence of other sellers, business capital, income/ income, allocation of business results, work/ business, how to solve problems in running business, activity in manufacturing, encouragement to learn, in sales/marketing, quality in products sold, and inheritance in running a business.

\subsection{Discussion of Research Results}

Local businesses in the city of Barabai as a source of economic learning in high school, contribute to the role of economic actors in economic activities as the main job and are a source of income for wadai apam sellers in the family. The linkage of local businesses as a source of high school economic learning can be seen from the examples of material and basic competency related to the role of economic actors in economic activities based on the findings, namely:

Table 3 Learning Competence

\begin{tabular}{|c|c|c|}
\hline Basic competencies & Learning materials & Actor Traders as Distributors \\
\hline $\begin{array}{l}\text { Grade } 10 \\
\text { KD } 3.3 \\
\text { Analysis of the role of economic } \\
\text { actors in economic activities }\end{array}$ & $\begin{array}{l}\text { Distribution } \\
\text { (Definition of distribution, the } \\
\text { purpose of distribution } \\
\text { activities, parties implementing } \\
\text { distribution activities, as well } \\
\text { as activities in distribution } \\
\text { activities }\end{array}$ & $\begin{array}{l}\text { 1) Daily activities such as selling or peddling } \\
\text { wadai apam barabai and other pastries } \\
\text { 2) Activities in distribution such as buying and } \\
\text { reselling these merchandise } \\
\text { 3) Activities in its promotion as a tool to attract } \\
\text { consumers' hearts }\end{array}$ \\
\hline
\end{tabular}

\section{CONCLUSION}

Based on the research results, it can be concluded that a small proportion of residents in the city of Barabai depend for their livelihood as sellers of wadai apam barabai. Where this business is the main job and also a source of income for those in the family. Local businesses in the city of Barabai in selling wadai apam barabai can be used as a source of high school economics learning, because seen from their activities as traders or sellers, they are related to economic activity material with basic competencies in analyzing the role of economic actors in economic activity.

\section{REFERENCES}

[1] A. Nugroho and L. Mareza, "Pemanfaatan Museum BRI dan Museum Jenderal Sudirman sebagai sumber belajar IPS oleh siswa dan guru SD dI Purwokerto," Khazanah Pendidik., vol. 9, no. 2, 2016.

[2] D. Daryanto, "Media pembelajaran," Yogjakarta, Gava Media, 2010.

[3] I. Wiryokusumo, "Mustaji. 1989," Pengelolaan Sumber Belajar.

[4] M. Pendidikan, "Peraturan Menteri Pendidikan dan Kebudayaan Republik Indonesia Nomor 21 Tahun 2016 tentang Standar Isi Pendidikan Dasar dan Menengah," Jakarta Menteri Pendidik. dan Kebud. Republik Indones., 2016.

[5] E. H. Widiastuti, "Pemanfaatan Lingkungan Sebagai Sumber Pembelajaran Mata Pelajaran IPS," Satya Widya, vol. 33, no. 1, pp. 29-36, 2017.
[6] S. Sutikno, B. Nasrul, H. Gunawan, R. Jayadi, E. Saputra, and K. Yamamoto, "The effectiveness of canal blocking for hydrological restoration in tropical peatland," in MATEC Web of Conferences, 2019, vol. 276, p. 6003, doi: 10.1051/matecconf/201927606003.

[7] H. HERIANTO, “Telaah Kurikulum 2013: Hasil Revisi Tahun 2018,” 2020.

[8] R. Abdullah, "Pembelajaran berbasis pemanfaatan sumber belajar," J. Ilm. Didakt. Media Ilm. Pendidik. dan Pengajaran, vol. 12, no. 2, 2012.

[9] S. Sukirno, "Makroekonomi teori pengantar," Jakarta PT Raja Graf. Perkasa, 2004.

[10] B. P. Sitepu, "Pengembangan sumber belajar," Jakarta Rajawali Pers, 2014.

[11] J. Musfah, Peningkatan kompetensi guru: Melalui pelatihan dan sumber belajar teori dan praktik. Kencana, 2012.

[12] W. K. Jaya, "Ekonomi industri," Ed. Kedua. Yogyakarta (ID). Fak. Ekon. Pr, Univ. Gajah Mada, 2001.

[13] Slameto, Belajar dan Faktor-faktor yang Mempengaruhinya. Bina Aksara, 1988.

[14] A. Anggito and J. Setiawan, Metodologi penelitian kualitatif. CV Jejak (Jejak Publisher), 2018.

[15] S. Sugiyono, "Metode penelitian kuantitatif dan kualitatif dan R\&D.” Alfabeta Bandung, 2010.

[16] A. Suharsimi, "Prosedur penelitian suatu pendekatan praktik," Jakarta: Rineka Cipta, 2006. 
[17] N. Jalmur, Media dan sumber pembelajaran. Kencana, 2016.

[18] I. Nuraini, Pengantar Ekonomi Mikro. UMMPress, 2016.

[19] S. Supriadi, "Pemanfaatan Sumber Belajar dalam Proses Pembelajaran,” Lantanida J., 2017.
[20] P. D. Merida and M. Witjaksono, "Optimalisasi Sumber Belajar Ekonomi dalam Pembelajaran Ekonomi di SMA," J. Pendidik. Teor. Penelitian, dan Pengemb., vol. 1, no. 12, pp. 2373-2378, 2016. 